\title{
The Effect of Students' Perceptions of Career Information Services on Students' Career Decision Making Self-Efficacy
}

\author{
Umi Haryati $^{1 凶}$, Edy Purwanto $^{2}$, Awalya Awalya $^{2}$ \\ 1. SMK Negeri 8 Semarang, Indonesia \\ 2. Universiatas Negeri Semarang, Indonesia
}

\begin{tabular}{|c|c|}
\hline Article Info & Abstract \\
\hline $\begin{array}{l}\text { History Articles } \\
\text { Received: } \\
15 \text { May } 2021 \\
\text { Accepted: } \\
18 \text { Juny } 2021 \\
\text { Published: } \\
30 \text { August } 2021\end{array}$ & $\begin{array}{l}\text { Lack of information related to education, position, or work that matches } \\
\text { students' abilities is one of the obstacles that cause students unable to make } \\
\text { appropriate career decisions. The purpose of this study was to empirically } \\
\text { examine the effect of students' perceptions of career information services on } \\
\text { career decision making self-efficacy. It involved } 108 \text { SMK students selected by } \\
\text { quota random sampling technique. The data analysis technique used was } \\
\text { simple linear regression analysis with the help of SPSS } 24 \text {. The results showed }\end{array}$ \\
\hline $\begin{array}{l}\text { Keywords: } \\
\text { Career Information } \\
\text { Service; Students } \\
\text { Perceptions; Self- }\end{array}$ & $\begin{array}{l}\text { that there was a significant relationship between students' perceptions of career } \\
\text { information services on career decision making self-efficacy by } 16 \% \text { ( } \beta=0.40 \text {, } \\
\text { p }<0.01 \text { ). The quality of good career information services will affect the self- } \\
\text { efficacy of good career decision making }\end{array}$ \\
\hline
\end{tabular}

Efficacy 


\section{INTRODUCTION}

Guidance and counseling activities in schools can be in form of career guidance information services. In providing career information services, guidance and counseling or BK teachers must have an ability to provide an optimal career guidance service process consistently and be able to develop a curriculum that is suitable for students (Lestari \& Supriyono, 2016). The process of providing optimal career guidance services can be realized if it is carried out by professional teachers (Albisri, 2017). Career information service as one of the guidance and counseling services should be student-centered. The success of career guidance service activities can be seen from students' perceptions of career guidance services (Sadewi et al., 2019).

Through perception, humans are constantly in touch with their environment. This relationship is done through senses, namely the senses of sight, hearing, touch, smell. Perception takes place when a person receives a stimulus from the outside world captured by his auxiliary organs which then enters the brain. In it, there occurs a process of thinking which ultimately manifests in an understanding. This understanding is more or less called perception. Students' perceptions of this career information service need to be known with the consideration that students are the main target of the guidance and counseling program provided by school. Thus, some appropriate adjustments can be made so that this career guidance gets an interesting appreciation by students. Regarding guidance and counseling, there are many perceptions that develop among students, including that guidance and counseling are very boring, unattractive, and sleepy. In addition, the provision of career guidance is expected to change students' perceptions of guidance and counseling, especially career guidance, to no longer be scary anymore (Asfarina et al., 2016).

The results of a preliminary survey conducted by the researchers on 60 vocational students in the city of Semarang showed that $60 \%$ of their career aspirations was entrepreneurs, employees and 20\% successful people. This shows that their mindset about the types of careers is still narrow, even though there are so many career options available. Meanwhile, on the Sinar Harapan Daily (28 May 2019), 2018 Susenas data indicate that $61 \%$ of vocational students did not understand where they should take further education. In a state of urgency like this, adolescents' decisions to choose majors are influenced by parents and peer groups (peers) advice which is obviously subjective. The results of interviews conducted by the author to 10 vocational students in the city of Semarang showed that most students did not understand their talents, interests and various kinds of information about careers. This can be seen from their answers, namely from 10 students, 8 of them were still unsure about the career choice to be taken even though they have chosen majors that have been adjusted to their career interests.

This condition is inversely proportional to the career development process in which children need to develop an understanding of time perspective in seeing their future (Rohmawati, 2019). Children need to have an understanding of the future based on current decisions such as choosing a secondary school that will affect their career choices later. By having career awareness, children will have broad insight into the types of work that exist in the world, set goals professionally and achieving goals (Yasmiri et al., 2017). It also enables them to have an important foundation in planning for the future effectively (Chan, 2020), play a role in making decisions in life, gain success and resilience in overcoming various situations that will arise in life and the world of work (Glessner et al., 2017).

One of the assumptions that guide this study was that effective career decision making is closely related to self-efficacy on one's career decision making ability (Bisri et al., 2018). Low self-efficacy in career decision making is related to individual's ignorance of their strengths and weaknesses, the absence of information about career plans, having no ability to set goals, having no skill to make career plans, and 
unsolvable problems related to their careers (Khumaeroh et al., 2019; Wright et al., 2020). Meanwhile, students who have high self-efficacy in career decisions are supposed to successfully perform tasks related to career decisions (Marcionetti \& Rossier, 2019).

The low understanding of students' careers at Vocational School or SMK in Semarang is certainly inseparable from various problems, so it is interesting to study based on supporting literature references, such as a study by Oktavia, (2018) which reports that $90 \%$ of high school students in Bandung Regency express doubts in choosing their careers, Fadli et al., (2019) who revealed that individuals should be encouraged to explore career dilemmas and allow them to maintain and improve their potential continuously by adaptation. Career information services are very useful for both students and their parents in terms of choosing further study majors, or trying to choose the right job. This makes the basis for the need for assistance so that students can make realistic and appropriate choices. Through career information service, it is hoped that SMK students in Semarang City will get some help to receive and understand various information that is used as consideration in making career decisions.

This study aimed to analyze the effect of students' perceptions of career information services on the students' career decision making self-efficacy. It is expected to provide inputs into career information service activities for counselors in order to increase self-efficacy of career decision making.

\section{METHODS}

The population in this study were all students of class XII SMK in the city of Semarang selected from a total 11 State Vocational Schools consisting of 12 classes of grade XII in every State Vocational School in Semarang City. In this study, the researchers used a quota random sampling technique because the study was conducted in three schools that have implemented career information services according to the service standards and procedures as well as based on demography located in the middle of the city, suburbs and remote areas of the city. The schools were SMK N 3 Semarang, SMK N 8 Semarang and SMK N 11 Semarang with a total of 108 students.

Student's perception data of career information services and career decision making self-efficacy data were collected using a Likert scale of 1-4. The scale was developed by the researchers themselves. In addition, to determine the level of validity and reliability of the items of the research instrument, a research instrument was first tested in the validity and reliability tests. Based on the calculation, there obtained three invalid question items from 20 items about student's perceptions of career information services and 3 invalid statement items from 30 students' career decision making self-efficacy statements. The reliability test of the questionnaire in this study was tested using Alpha Crounbach formula and gained the results of 0.750 on the student's perception item and 0.867 on the career decision making self-efficacy item.

\section{RESULTS AND DISCUSSION}

The analysis of the effect of students' perceptions of career information services on career decision making self-efficacy of class XII SMK students in Semarang City was performed using SPSS 24 correlation test application with enter method. Basically, there are several types of methods that can be used distinguished based on the type of output or output produced although the result value remains the same. The researchers chose to use this method because this method is simple, and the output data produced were in accordance with what was needed as stated in the results of this study.

The results of the regression analysis as contained in Table 1 indicate that there was a positive relationship between perceptions of career information services and career decision making self-efficacy $(\beta=0.40, p<0.01)$. Students' perceptions of career information services explain the variance of self-efficacy of career 
decision making by $16 \%(\mathrm{R} 2=0.16)$. This meant that the higher the student's perception of the student's career information service, the higher the self-efficacy of the student's career decision making ability. The magnitude of the correlation or relationship (R) between students' perceptions of career information services on career decision making self-efficacy was 0.40 .

The results of the regression analysis showed that the perception of career information services contributed positively to the self-efficacy of students' career decision making abilities. Students who received career information services will positively evaluate the career information services they receive, so career information service is used as a source of consideration in making future career decisions. The more career information students receive, the more they will shape their career understanding to support students in making career decisions. Therefore, the quality of career information services and career understanding are factors that contribute to improving students' career decision making abilities.

The results of the regression analysis also showed that the perception of career information services partially contributed to the self-efficacy of students' career decision making. The results of this study support the opinion of Fatimah et al., (2012) that career information services are a form of guidance to assist students in planning, developing and solving career problems, such as understanding of positions and work tasks, understanding of conditions and abilities, understanding environmental conditions, planning and career development, job adjustment and solving career problems being faced. Yatmawati (2019) argues that careers begin to be built and developed since school or called as a desired goal related to a particular field of education, work or a profession. The educational period that students pass in SMK will be very meaningful in fostering and finalizing the preparation of job choices and preparing work plans that are suitable for each of them (Dumulescu et al., 2015). Accurate information about the world of work and oneself is important to influence adolescents' perceptions of career decisions so that adolescents can adjust career choices to their potential (Wu et al., 2012). Career information services for individuals who are in the exploration stage help individuals understand relevant factors and gain experience in making career choices, exploring fields of work in relation to their interests and abilities, making plans and developing strategies for achieving them (Khairun et al., 2016).

The perception of career information services in this study was found significantly influence self-efficacy in making career decisions. The success of career guidance in selfefficacy in making career decisions can occur because it uses a cognitive social approach (Anggita et al., 2021). Social cognitive theory according to Bandura (1997) emphasizes the view of someone who is active and as a user of cognitive processes to describe events, anticipate the future, choose actions and communicate with others (in Pervin \& John, 2001). Bandura in his theory emphasizes the importance of selfperception (self-efficacy) as a cognitive mediator in acting. While considering his or her actions, a person makes decisions about his or her ability to perform those actions (assessment of selfefficacy). Self-efficacy assessment will affect a person's thoughts, emotions and actions in achieving his goals. Next, someone will set standards and goals and make judgments about the ability to perform tasks or take actions. Based on this description, students' perceptions of career information services can contribute to the self-efficacy of students' career decision making. School needs to take steps to improve the quality of career information services as well as understand students' career interests effectively so that students have the ability to make good career decisions.

Based on the results of a study on the effect of students' perceptions of career information services on career decision making self-efficacy, it was found that the students' perceptions of career information services on career decision making self-efficacy had a significant value. This was because career understanding provides a clear and accurate 
picture of the world of work and career decision making information. This means that career information services will provide a good understanding of careers so that they have the closest relationship with career decisions. Someone who has a career understanding knows various information about careers and how to make career decisions.

\section{CONCLUSION}

Perceptions of career information services have a positive effect on self-efficacy in making career decisions by class XII SMK students in Semarang City. The higher the level, the better (higher) students' perception of career information services, and the higher the selfefficacy of students' career decision making abilities. If it is associated with the career guidance process, prior to making decisions, students determine the targets to be achieved according to the degree of confidence that they can meet those targets well. After that, the individuals learn from their or others experience by doing self-reflection and seeing the behavior of others, then critically analyzing it so that they will find new understanding. During the process of discovering new understandings, individuals will experience a learning process from their experiences and their environment.

Suggestions from the results of this study are, 1) school counselors are hoped to provide guidance and counseling services better according to student's needs so that students have a better perception of social information services. It is also recommended to accompany the development of self-efficacy in student's career decision making more intensively in an effort to help develop students' self-adjustment abilities, 2) the future researchers who are interested in investigating the effect of perceptions of career information services on career decision making self-efficacy are expected to control independent variables before conducting the study. This suggestion is addressed to similar type of study, namely ex post facto. Then the results that will be obtained will be more in line with what they should be, namely dependent variable is only influenced by independent variable intended in the study.

\section{REFRENCES}

Anggita, T., Sugiyo, S., \& Awalya, A. (2021). Improving self-efficacy with cognitive restructuring and self instruction: An experimental study in senior high school. KONSELI: Jurnal Bimbingan dan Konseling (E-Journal), 8(1), 09-14. http://103.88.229.8/index.php/konseli/a rticle/view/8852

Asfarina, A., Ibrahim, I., \& Said, A. (2016). Persepsi Siswa tentang Pelaksanaan Bimbingan Karir. Konselor, 5(2), 108. https://doi.org/10.24036/020165265480-00

Bisri, M., Purwanto, E., \& Japar, M. (2018). The Effectiveness of Group Counselling with Modelling Technique to Improve Self-Efficacy in Senior High School Students Decision Making of Study Continuation. Jurnal Bimbingan Konseling, 7(1), https://journal.unnes.ac.id/sju/index.ph $\mathrm{p} / \mathrm{jubk} /$ article/view/22281

Chan, C. C. (2020). Social support, career beliefs, and career self-efficacy in determination of Taiwanese college athletes' career development. Journal of Hospitality, Leisure, Sport and Tourism Education, 26(March), 100232. https://doi.org/10.1016/j.jhlste.2019.100 232

Dumulescu, D., Balazsi, R., \& Opre, A. (2015). Calling and Career Competencies among Romanian Students: The Mediating Role of Career Adaptability. Procedia - Social and Behavioral Sciences, 209, 25-32. https://doi.org/10.1016/j.sbspro.2015.11 .223

Fadli, R. P., Mudjiran, M., Ifdil, I., \& Amalianita, B. (2019). Peluang dan tantangan bimbingan karir di sekolah menengah kejuruan pada era revolusi industri 4.0. Jurnal EDUCATIO: Jurnal 
Pendidikan Indonesia, 5(2), 102
https://doi.org/10.29210/120192395

Fatimah, S., Suherman, M. M., \& Rohaeti, E. E. (2019). Pelatihan Penerapan Metode PLANS untuk Mengembangkan Efikasi Diri Dalam Pengambilan Keputusan Karier Siswa di Kabupaten Purwakarta. 9(2), 121-130.

Glessner, K., Rockinson-Szapkiw, A. J., \& Lopez, M. L. (2017). "Yes, I Can": Testing an Intervention to Increase Middle School Students' College and Career Self-Efficacy. Career Development Quarterly, 65(4), 315-325. https://doi.org/10.1002/cdq.12110

Khairun, D. Y., Sulastri, M. S., \& Hafina, A. (2016). Kematangan Eksplorasi Karir Siswa. Jurnal Penelitian Bimbingan Konseling, 1(1), 1-23.

Khumaeroh, S., Purwanto, E., \& Awalya, A. (2019). Self-Efficacy, Goal Orientations, and Religious Moral Orientations on Academic Dishonesty. Jurnal Bimbingan Konseling, 8(3), 20-25. https://journal.unnes.ac.id/sju/index.ph $\mathrm{p} / \mathrm{jubk} /$ article/view/28748

Lestari, D., \& Supriyono. (2016). Kontribusi Minat Jurusan, Kualitas Layanan Informasi Karir, dan Pemahaman Karir terhadap Kemampuan Mengambil Keputusan Karir. Jurnal Bimbingan Konseling, $\quad 5(1), \quad 47=54-47=54$. http://journal.unnes.ac.id/sju/index.php $/ \mathrm{jubk} \% 0 \mathrm{~A}$

Marcionetti, J., \& Rossier, J. (2019). A Longitudinal Study of Relations Among Adolescents' Self-Esteem, General SelfEfficacy, Career Adaptability, and Life Satisfaction. Journal of Career Development, $1-16$. https://doi.org/10.1177/0894845319861 691

Oktavia, N. D. A. (2018). Hubungan Antara Efikasi Diri Dan Motif Berprestasi Dengan Daya Juang Pada Mahasiswa Bimbingan Dan. 16, 125-138.
Rohmawati, N. (2019). Kemandirian Siswa dalam Merencanakan Karir Ditinjau dari Persepsi Siswa Tentang Pelaksanaan Layanan Bimbingan Karir. Indonesian Journal of Guidance and Counseling: Theory and Application, 8(2), 67-73. https://doi.org/10.15294/ijgc.v8i2.22762

Sadewi, A. I., Wibowo, M. E., \& Sugiyo, S. (2019). Group counseling with symbolic modeling technique to improve students career decision making self-efficacy. Jurnal Bimbingan Konseling, 8(2), 163-167. https://journal.unnes.ac.id/sju/index.ph p/jubk/article/view/28296

Vatmawati, S. (2019). Hubungan Konformitas Siswa Dengan Pengambilan Keputusan Karir. EMPATI-Jurnal Bimbingan Dan Konseling, https://doi.org/10.26877/empati.v6i1.41 14

Wright, S. L., Kacmarski, J. A., Firsick, D. M., Jenkins-Guarnieri, M. A., \& Kimm, A. J. (2020). Family Influences on College Students' Anticipated Work-Family Conflict, Social Self-Efficacy, and SelfEsteem. Career Development Quarterly, 68(2), 112-128. https://doi.org/10.1002/cdq.12217

Wu, L. M., Austin, J., Hamilton, J. G., Valdimarsdottir, H., Isola, L., Rowley, S., Warbet, R., Winkel, G., Redd, W. H., \& Rini, C. (2012). Self-efficacy beliefs mediate the relationship between subjective cognitive functioning and physical and mental well-being after hematopoietic stem cell transplant. Psycho-Oncology, 21(11), 1175-1184. https://doi.org/10.1002/pon.2012

Yasmiri, Y., Syah, N., Ambiyar, A., \& Hamid, M. A. (2017). Evaluasi Program Layanan Bimbingan Karir dengan Model Kirkpatrick di SMK Negeri 1 Kecamatan Guguak Kabupaten Lima Puluh Kota. VOLT: Jurnal Ilmiah Pendidikan Teknik Elektro, 2(1), 23. https://doi.org/10.30870/volt.v2i1.1479 